\title{
$\alpha \mathbf{A}$-crystallin R49Cneo mutation influences the architecture of lens fiber cell membranes and causes posterior and nuclear cataracts in mice
}

\author{
Usha P Andley
}

Address: Department of Ophthalmology and Visual Sciences, Washington University School of Medicine, St Louis, Missouri, USA

Email: Usha P Andley - andley@vision.wustl.edu

Published: 20 July 2009

BMC Ophthalmology 2009, 9:4 doi:10.1/86/147|-24|5-9-4

This article is available from: http://www.biomedcentral.com/I47|-24/5/9/4

(C) 2009 Andley; licensee BioMed Central Ltd.

This is an Open Access article distributed under the terms of the Creative Commons Attribution License (http://creativecommons.org/licenses/by/2.0), which permits unrestricted use, distribution, and reproduction in any medium, provided the original work is properly cited.
Received: 23 December 2008

Accepted: 20 July 2009

\begin{abstract}
Background: $\alpha$ A-crystallin (CRYAA/HSPB4), a major component of all vertebrate eye lenses, is a small heat shock protein responsible for maintaining lens transparency. The R49C mutation in the $\alpha A$-crystallin protein is linked with non-syndromic, hereditary human cataracts in a four-generation Caucasian family.

Methods: This study describes a mouse cataract model generated by insertion of a neomycinresistant (neor) gene into an intron of the gene encoding mutant $\mathrm{R} 49 \mathrm{C} \alpha \mathrm{A}$-crystallin. Mice carrying the neor gene and wild-type Cryaa were also generated as controls. Heterozygous knock-in mice containing one wild type gene and one mutated gene for $\alpha A$-crystallin (WT/R49Cneo) and homozygous knock-in mice containing two mutated genes (R49Cneo/R49Cneo) were compared.
\end{abstract}

Results: By 3 weeks, WT/R49Cneo mice exhibited large vacuoles in the cortical region $100 \mu \mathrm{m}$ from the lens surface, and by 3 months posterior and nuclear cataracts had developed. WT/ R49Cneo mice demonstrated severe posterior cataracts at 9 months of age, with considerable posterior nuclear migration evident in histological sections. R49Cneo/R49Cneo mice demonstrated nearly complete lens opacities by 5 months of age. In contrast, R49C mice in which the neor gene was deleted by breeding with CreElla mice developed lens abnormalities at birth, suggesting that the neor gene may suppress expression of mutant R49C $\alpha \mathrm{A}$-crystallin protein.

Conclusion: It is apparent that modification of membrane and cell-cell interactions occurs in the presence of the $\alpha A$-crystallin mutation and rapidly leads to lens cell pathology in vivo.

\section{Background}

Cataracts involving mutations in lens crystallin genes have received considerable attention in recent years [1-5]. Vertebrate lens crystallins are divided into two families, $\alpha$ and $\beta \gamma . \alpha$-crystallin is essential for lens transparency and accounts for nearly $50 \%$ of the protein mass in human lenses. It is a large multimeric complex with an aggregate molecular mass of $500,000-1,200,000 \mathrm{Da}$, and is isolated from lens fiber cells as a complex of $\alpha \mathrm{A}$ - and $\alpha \mathrm{B}$-crystallin in a 3:1 stoichiometry [6]. $\alpha \mathrm{A}$-crystallin/HSPB4 is a member of the small heat shock protein family, which also includes $\alpha \mathrm{B}$-crystallin/HSPB5 and Hsp27/HSPB1 [7]. The etiology of lens disease is diverse, but a common pathological endpoint is the formation of large protein aggregates that scatter light. The capacity of $\alpha$-crystallins to efficiently trap aggregation-prone denatured proteins is thought to delay age-related cataract in humans. $\alpha$-crystallin and homoaggregates of $\alpha \mathrm{A}$ and $\alpha \mathrm{B}$-crystallin interact in 
vitro with non-native proteins and prevent their irreversible aggregation and insolubilization [8]. Using recombinant proteins, $\alpha \mathrm{A}$ and $\alpha \mathrm{B}$-crystallin have been shown to interact with many partially denatured substrates. Their stability, dynamic properties, and ability to transition from large assemblies to smaller dimeric and monomeric species appear to be critical for this chaperone ability [913]. The binding of $\alpha \mathrm{A}$ and $\alpha \mathrm{B}$-crystallin to misfolded proteins occurs with a high efficiency [14]; however, once all the $\alpha$-crystallin in lens fiber cells has been depleted, the concentration of irreversibly denatured proteins could increase, resulting in cataract. $\alpha \mathrm{A}$-crystallin binds to lens cell membranes and this association is increased in cataracts. Indeed, many models of cataract involve alterations in lens cell membranes [15-17]. The interaction of $\alpha$-crystallin with the cytoskeleton is also of major importance in maintaining lens transparency [18-22].

$\alpha \mathrm{A}-c r y s t a l l i n$ transcripts are present in mouse lens epithelium at embryonic day 10.5 and continue to be expressed during embryonic development and postnatally [23]. Studies on $\alpha$-crystallin knockout mice suggest that loss of $\alpha$ A-crystallin may increase the concentration of unstable proteins and affect the solubility of $\alpha \mathrm{B}$-crystallin and $\gamma$ crystallin $[24,25]$. In addition to its essential role in the optical and refractive properties of the eye lens, $\alpha \mathrm{A}$-crystallin performs other functions; $\alpha$ A-crystallin knockout mice exhibit increased lens epithelial cell death and reduced cell proliferation $[26,27]$, and $\alpha A$-crystallin is also expressed in the retina, brain, spleen, and thymus [28] although its role in these tissues is not fully understood.

Transfection studies show that $\alpha$-crystallins protect cells from stress-induced apoptosis [27]. Both $\alpha \mathrm{A}$ and $\alpha \mathrm{B}$-crystallin are negative regulators of apoptosis in lens cells $[29,30]$, and $\alpha \mathrm{A}$-crystallin knockout lens epithelial cells have a higher level of cell death than wild type cells [31]. Thus, cellular protection by crystallins may delay the onset of age-related and hereditary cataracts.

Several single-point mutations in $\alpha$-crystallins have been linked with hereditary human cataracts [1,32-37]. In $\alpha \mathrm{A}$ crystallin, R49C and W9X mutations in the N-terminal domain, and R116C, R116H, and G98R mutations in the $\mathrm{C}$-terminal domain cause human cataracts, as do C-terminal R120G, 450delA, D140N mutations in aB-crystallin. Many of these mutations are inherited by autosomal dominant mechanisms. Study of these $\alpha \mathrm{A}$-crystallin gene mutations would enhance our understanding of the mechanisms of cataract formation [1,5,32,34,37-39]. Mutations in $\alpha \mathrm{A}$-crystallin increase the abundance of aggregation-prone proteins. In vitro studies suggest that mutant $\alpha \mathrm{A}$-crystallin may aggregate causing increased coprecipitation of substrate proteins [40-43]. The most com- mon effect of single-point mutations and truncations is an increase in the size of the oligomeric complex [44-46]. The R49C mutant of $\alpha \mathrm{A}$-crystallin has a slightly higher mass and radius of gyration, but the main effect of the mutation is increased protein insolubility [42]. Arginine is a highly charged residue, and its replacement by the less polar cysteine might alter protein assembly and solubility. Moreover, the positive charge on arginine 49 has been highly conserved during evolution, and is important for in vitro chaperone activity of $\alpha$ A-crystallin $[47,48]$.

Several model systems are available to study the effect of single-point mutations of crystallin genes. Transgenic mice have been used to investigate the effect of the R116C mutation in aA-crystallin in vivo [49], and several studies have used transfected cells expressing mutant proteins $[1,38,50]$. Naturally occurring and mutagenesis-induced mouse models have also been analyzed [51-54]. Naturally occurring $\alpha \mathrm{A}$-crystallin mutations in mice are Cryaa lop1 $(\mathrm{R} 54 \mathrm{H})$, and Cryaa R54C mutations in the N-terminal region, and Y118D and Cryaa Aey7 (V124E) mutations in the C-terminal domain. While significant information has been obtained by studying mutant $\alpha \mathrm{A}$-crystallin in vitro, such studies have certain limitations. Mutations affecting protein interactions at low concentrations may have little relevance to how they associate in vivo at higher concentrations in the lens. Thus, an optimal model must investigate the effect of the mutation in vivo. To study the mechanism of hereditary cataracts, this laboratory recently generated R49C knock-in mice and compared wild type lenses with heterozygous and homozygous mutant lenses to investigate gene dosage effects $[42,55]$. While generating the R49C knock-in mice, in which the floxed neo cassette was deleted by mating with Cre deletor mice, we serendipitously created WT/R49Cneo and R49Cneo/R49Cneo mouse cataract models which show milder lens effects in vivo, thus allowing examination of the effects of the mutant protein at potentially changed levels of expression. The aim of the present study was to characterize the lens abnormalities in WT/R49Cneo and $\mathrm{R}_{4} \mathrm{C}^{\text {neo/R}} \mathrm{R}$ 9C neo mice and compare these with previous reports of WT/R49C and R49C/R49C lenses [42,55].

\section{Methods \\ Animals}

Mice were maintained at Washington University Division of Comparative Medicine by trained veterinary staff. All protocols and animal procedures were approved by the Washington University Animal Studies Committee. Lens opacity was monitored by slit lamp biomicroscopy. The left eye of the animals was examined, and pupils were dilated with a mixture of $10 \%$ phenylephrine hydrochloride and $1 \%$ tropicamide (Alcon, Fort Worth, Texas). Mice carrying the $\mathrm{R} 49 \mathrm{C}^{\text {neo }}$ locus were generated from one embryonic stem cell clone (129 background) as previ- 
ously described [55]. This locus carries a neomycin cassette flanked by lox P sites inserted into an XhoI site in intron 1 of Cryaa. One ES clone with the neo insertion but no Cryaa mutation was used to generate WT/WTneo and WTneo/WTneo mice. Two lines of mice expressing the mutation in Cryaa, R49CneoKI3 and R49CneoKI4, were bred. Another mouse line, WTneoKI2, expressing wild type Cryaa was also generated on 129 background. Mice containing one copy of the targeted knock-in allele (heterozygous mice) were interbred to generate homozygous mice. Genotyping primers were used to identify the knock-in construct containing the neomycin cassette as described previously [55]. Transgenic mice expressing Cre-EIIa on a C57BL/6 background were bred with homozygous Cryaa knock-in mice to delete the neor gene. These mice were described in previous studies $[42,55]$.

\section{Slit lamp examination}

Dilated mouse eyes were examined in unanesthetized mice. Stages of cataracts were defined as follows: Stage 0 clear lens; Stage 1 - loss of normal appearance of posterior lens and prominence of y-suture line; Stage 2 - discrete posterior changes accompanied by light nuclear opacity; Stage 3 - nearly mature cataract, involving approximately three-fourths of the lens with bubbles and opacity; Stage 4 - completely mature cataract involving the cortex with bubbles and vacuoles.

\section{Histology}

For conventional histology, eyes were fixed overnight at $4^{\circ} \mathrm{C}$ in formalin (Sigma, St. Louis, MO). After a thorough wash in phosphate-buffered saline, lenses were dehydrated through graded acetone and infiltrated in methacrylate resin (H-8100; Technovit, Kulzer, Germany) according to the following schedule: 1:2 resin:acetone, 1 day; $1: 1$ resin:acetone, 1 day; $100 \%$ resin, 4 days. Blocks were polymerized for 1 hour at $4{ }^{\circ} \mathrm{C}$. Sections $(3 \mu \mathrm{m})$ were cut and stained with haematoxylin and eosin.

\section{Immunofluorescence}

Immunofluorescence was performed as previously described [31]. Primary antibody to lens membrane intrinsic protein MIP was purchased from Alpha Diagnostics International. Alexa ${ }^{568}$-labeled secondary antibody (Molecular Probes) was used at 1:500 dilution.

\section{Immunoblotting}

Lens extracts were separated into water-soluble and insoluble fractions, and examined by SDS-PAGE and immunoblotting with an antibody to $\alpha$-crystallin [56]. Protein concentration of the water-soluble fractions was determined by the bicinchoninic acid (BCA) protein assay according to the manufacturer's instructions (Thermo Scientific-Pierce Chemical Co, Rockford IL). 40-50 $\mu \mathrm{g}$ of extract was loaded on the gel. The primary antibody was either a polyclonal antibody (used at 1:500 dilution) to total $\alpha$-crystallin or a monoclonal antibody (a gift from Dr. Paul FitzGerald; used at 1:100 dilution) to $\alpha$ A-crystallin, and horseradish peroxidase-conjugated secondary antibodies as described previously $[27,42,56]$. The relative intensity of the mouse $\alpha$ A-crystallin band at approximately $20 \mathrm{kDa}$ was analyzed by Image J software. The decrease in $\alpha \mathrm{A}$-crystallin soluble protein with increasing numbers of R49Cneor-containing genes was calculated as the mean of three independent experiments.

\section{Cryoimmuno electron microscopic analysis}

Lens sections were examined by cryoimmuno electron microscopy. Sections $(50-80 \mathrm{~nm})$ were treated with a primary monoclonal antibody to $\alpha \mathrm{A}$-crystallin [27] and antimouse IgG conjugated with $18 \mathrm{~nm}$ gold particles as secondary antibody (Sigma). Specimens were stained with uranyl acetate and examined in a 1200EX transmission electron microscope as described previously [57].

\section{Analytical chromatography and analysis}

WT/WTneo and WT/R49Cneo mouse lenses (1.5 to 2.5 month old) were used to isolate water-soluble proteins [42]. Six lenses of each genotype were homogenized in $500 \mu \mathrm{l}$ of phosphate-buffered saline (Sigma) and the water-soluble protein fraction was separated by centrifugation at 15,000 g. FPLC chromatography was performed on a chromatography system containing an inline detector for UV absorption at $280 \mathrm{~nm}$. A $16 \mathrm{~cm} \times 60 \mathrm{~cm}$ Superdex 200 column (GE Healthcare Biosciences) equilibrated with $10 \mathrm{mM}$ Tris.Cl; pH 6.8 containing $100 \mathrm{mM} \mathrm{NaCl}, 1$ $\mathrm{mM}$ DTT and $0.5 \mathrm{mM}$ EDTA was used. Proteins were injected at $1 \mathrm{mg} / \mathrm{ml}$ for different chromatographic runs. One $\mathrm{ml}$ fractions were collected, and proteins mass was determined by calibrated molecular mass standards. The area under each peak was used to determine changes in abundance of $\alpha, \beta$ and $\gamma$-crystallin fractions. The results are representative of 6 lenses per genotype. The analysis was repeated with almost the same results.

\section{Results}

While constructing a gene knock-in mouse model of R49C $\alpha$ A-crystallin, we generated mice carrying a floxed neo $^{\mathrm{r}}$ gene in an intron of the Cryaa gene (Figure 1). Mating these to a mouse expressing Cre recombinase resulted in removal of the neo cassette, leaving the loxp site adjacent to exon 1 of the Cryaa gene, and producing a functional but less active mutant allele $[42,55]$. Two lines of $\mathrm{R} 49 \mathrm{C}^{\text {neo }}$ mice, R49CneoKI 3 and $\mathrm{R} 49 \mathrm{C}^{\text {neo }} \mathrm{KI}$ 4, were generated from a single ES cell clone, and the results obtained from these two lines were very similar. The knock-in mice were viable and bred normally. Heterozygous WT/R49C neo mice were intercrossed to produce $\mathrm{R} 49 \mathrm{C}^{\text {neo/R49C }}$ (neo homozygous offspring. A control mouse line was also generated from an ES cell clone that had the neomycin cassette inserted, 

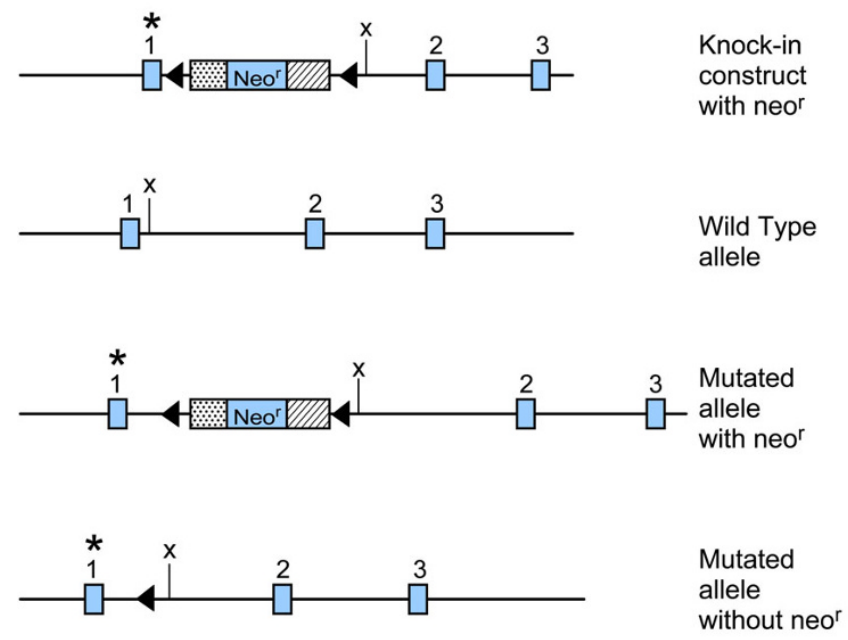

Figure I

Plasmid construct used to generate R49Cneo gene knock-in mice. The 5' and 3' arms of the $\alpha$ A-crystallin gene (Cryaa) were cloned into a vector containing the floxed neomycin (neo) cDNA. Mutagenesis was performed to mutate amino acid arginine 49 of $\alpha A$-crystallin to cysteine (R49C). The asterisk above exon I indicates the mutation. The numbered blue rectangles indicate exons. The filled triangles are loxP sites and $X$ denotes the $X$ hol site. Mouse embryonic stem (ES) cells SCC- 10 were electroporated with the mutant plasmid, and clones testing positive for neo were identified and used to generate $\mathrm{R} 49 \mathrm{C}^{\text {neo }} \alpha \mathrm{A}$-crystallin knock-in mice (WT/R49Cneo). One clone containing wild type (WT) $\alpha$ Acrystallin cDNA and neo was also analyzed and used to generate mice with the neo allele but no mutation (WT/WTneo).

but lacked the R49C $\alpha \mathrm{A}$-crystallin mutation. These mice did not have the altered lens phenotype, and served as a useful control. We speculated based on previous work by others [58-60] that the neor gene might exhibit diminished activity of mutant R49C gene that would provide novel insights into the biology of R49C $\alpha \mathrm{A}$-crystallin in vivo. To determine the effect of the R49Cneo gene on $\alpha$ crystallin protein expression, lenses were analyzed by gel permeation chromatography. Figure 2 shows the chromatography profile of water-soluble lens proteins of WT/ $\mathrm{WT}^{\text {neo }}$ and $\mathrm{WT} / \mathrm{R} 49 \mathrm{C}^{\text {neo }}$ mice measured by absorbance measurements at $280 \mathrm{~nm}$. The analysis showed a $30 \%$ decrease in expression of total $\alpha$-crystallin protein in WT/ $\mathrm{R} 49 \mathrm{C}^{\text {neo }}$ heterozygous lens as compared with wild type lenses. The expression of $\beta$-crystallins also decreased whereas $\gamma$-crystallin expression was not appreciably affected. As compared with WT/R49C lenses [42], $\alpha$-crystallin decreased more in the WT/R49Cneo lenses.

Lens opacities were confirmed in R49Cneo mutant mice by slit lamp analysis (Figure 3). By 3 months, R49Cneo mice showed evidence of opacities in posterior and nuclear regions. Over time, the cataract progressed to a nuclear

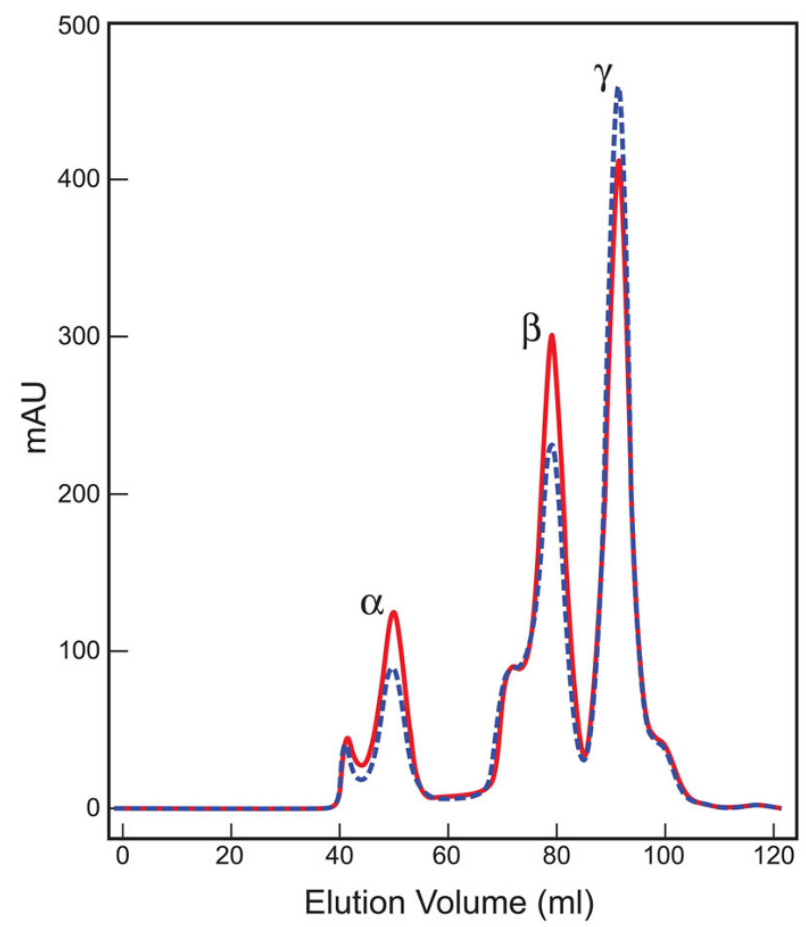

Figure 2

FPLC analysis of crystallins in WT/WTneo and WT/ $\mathbf{R} 49 \mathbf{C}^{\text {neo }}$ mouse lenses. UV absorption profile of watersoluble mouse lens proteins separated from WT/WTneo (red) and WT/R49C neo (blue) by gel permeation chromatography. Proteins were pooled from six lenses of each genotype at $\sim 2$-month-old. mAU represents milli absorbance units at 280 $\mathrm{nm}$.

cataract and then to an all-over opacity that included the cortical fibers (Figure 3A-D). Heterozygous mice at each age showed variable lens opacities ranging from clear (stage 0 ) at $<2$ months, stage 0 to stage 2 at 2-3 months, and clear to complete opacity (stage 4 ) at $>4$ months of age. Wild type mice did not show any of these abnormalities. At least four mice were examined for each genotype at a given age (Table $1 \mathrm{~A}$ ). The neomycin cassette was deleted by breeding homozygous $\mathrm{R} 49 \mathrm{C}^{\text {neo }}$ mice with CreEIIa transgenic mice. These neomycin-deleted R49C mutant mice had a more severe lens phenotype, with homozygous R49C/R49C knock-in neo-deleted mice exhibiting an opacity that covered three-quarters of the young lens (Figure 3E and 3F). Overall, cataract progression was more rapid in R49C/R49C mice than in R49Cneo/ R49Cneo mice.

Examination of $\alpha \mathrm{A}$-crystallin soluble protein revealed that some of these changes were due to protein insolubility (Figure 4). Mice with nuclear opacity ranging from stage 1 to stage 3 (by slit lamp analysis) were separated into water-soluble and insoluble fractions. Water-soluble frac- 

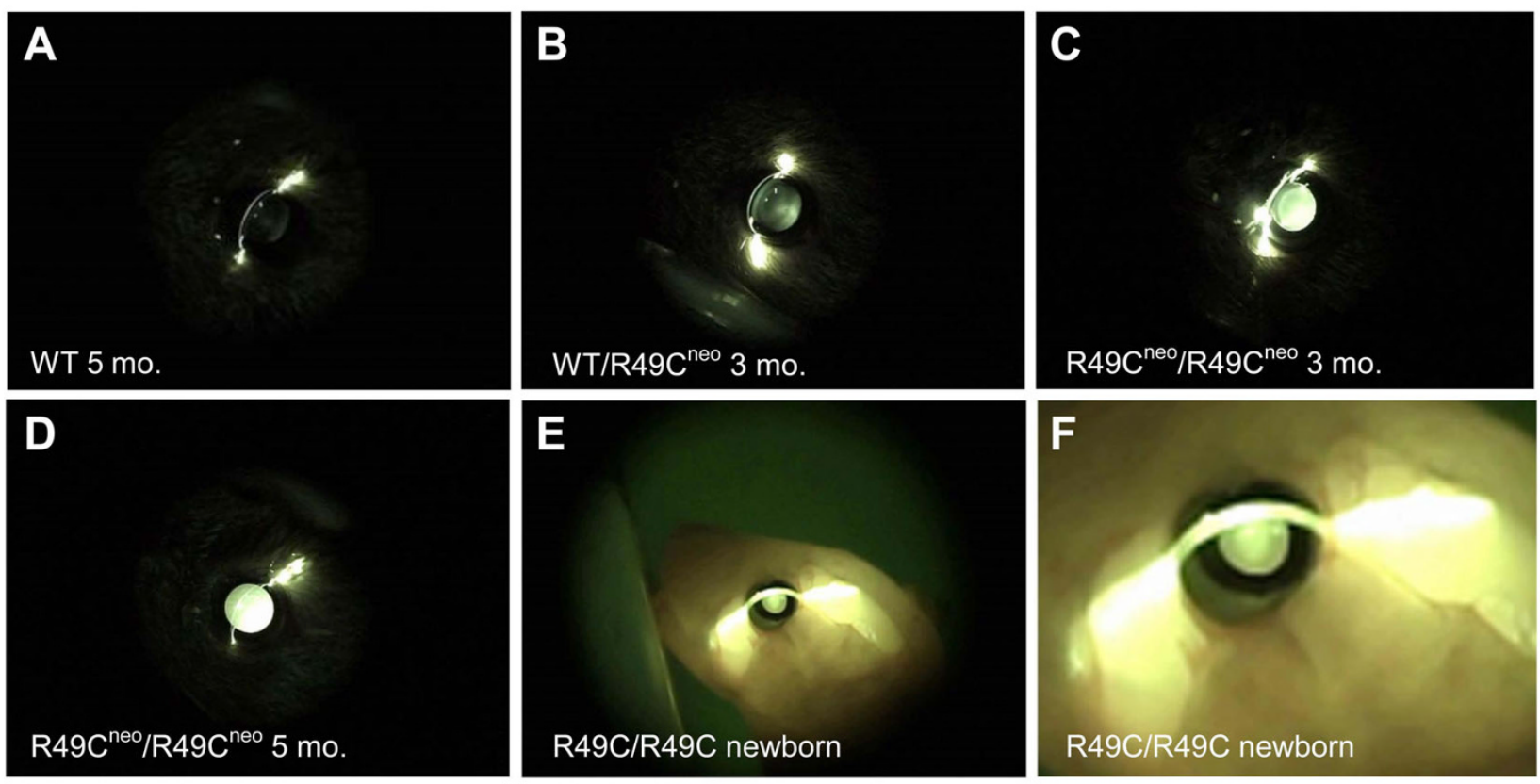

\section{Figure 3}

Lens phenotypes in R49 Cneo mice. (A-D) Eyes were dilated and examined by slit lamp. (A) Wild type mice (5 months old) had clear lenses (stage 0 ). (B) Heterozygous WT/R49Cneo $\alpha A$-crystallin knock-in mice ( 3 months old) had opacity in the posterior and nuclear regions of the lens (stage 2). (C) Homozygous R49Cneo/R49Cneo $\alpha$ A-crystallin knock-in mice (3 months old) had a nearly complete cataract (stage 3-4). (D) R49Cneo/R49C neo $\alpha A$-crystallin knock-in mouse lenses showed a complete cataract at 5 months (stage 4). (E, F) Cataract in lens of a newborn R49C/R49C homozygous mouse with deletion of the neor gene by Cre-recombinase. Slit lamp image $(E)$ shows a severe nuclear opacity at birth (stage 3$)$. (F) Higher magnification of the lens shown in (E) shows the nuclear opacity covering $\sim 70 \%$ of the lens.

Table I: Phenotypic changes in wild type (WT), WT/R49Cneo heterozygous, and R49Cneo/R49Cneo homozygous mice.

\begin{tabular}{lllll}
\hline A. Slit lamp analysis* & & & \\
\hline Genotype & Phenotype & Age Group & & \\
\cline { 2 - 5 } & Nuclear and posterior changes by slit lamp biomicroscopy & $<2$ month & $2-3$ months & $>4$ months \\
& & $0 / 4$ & $0 / 4$ & $2 / 9$ \\
WT & & $3 / 6$ & $14 / 22$ & $7 / 7$ \\
WT/R49Cneo & $4 / 5$ & $5 / 7$ & $13 / 14$ & $2 / 17(0.12)$ \\
R49Cneo/R49Cneo & & $22 / 26(0.85)$
\end{tabular}

\section{B. Histological analysis*}

\begin{tabular}{|c|c|c|c|c|c|}
\hline \multirow[t]{2}{*}{ Genotype } & \multirow{2}{*}{$\begin{array}{l}\text { Phenotype } \\
\text { Swollen cells and/or posterior changes by histology }\end{array}$} & \multicolumn{3}{|l|}{ Age Group } & \multirow[t]{2}{*}{ Total } \\
\hline & & $<$ I month & 2-3 months & $>4$ months & \\
\hline WT & & $0 / 5$ & $\mathrm{I} / 4$ & $\mathrm{I} / 7$ & $2 / 16(0.13)$ \\
\hline WT/R49Cneo & & $4 / 11$ & $2 / 4$ & $2 / 3$ & $8 / 18(0.44)$ \\
\hline R49Cneo/R49Cneo & & $4 / 5$ & $3 / 4$ & $6 / 8$ & $13 / 17(0.76)$ \\
\hline
\end{tabular}

* For each age group, the total number of mice analyzed is shown in the denominator, and the number of mice demonstrating the phenotype is shown in the numerator. The final columns show the total number of mice of each genotype that demonstrate a phenotype, with the proportion given in parentheses. 
A

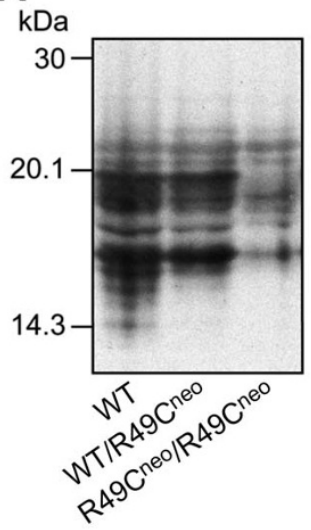

B

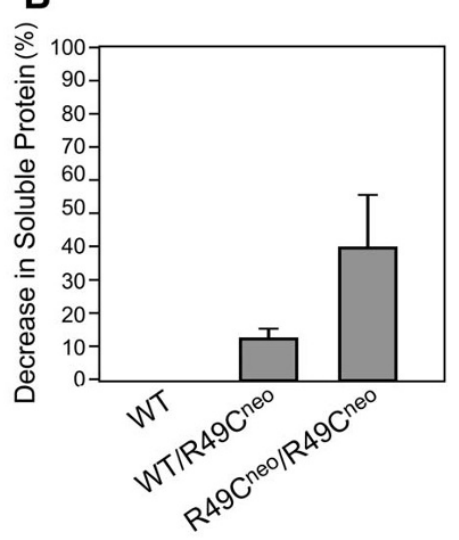

Figure 4

Water-soluble $\alpha$ A-crystallin in R49 Cneo knock-in lenses. Protein solubility was assessed in lenses with different nuclear cataract severity ranging from stage I to 3 as determined by slit lamp analysis. (A) WT lenses had the highest protein solubility by immunoblotting with an antibody to $\alpha$-crystallin. The wild type is clear lens (stage 0 ). A decrease in soluble protein levels was seen in the WT/R49Cneo lenses. R49Cneo/R49Cneo lenses had a significantly lower water solubility. Proteins were overloaded so that even a small amount of protein could be visualized. Under these conditions, crossreactivity of the antibody with other crystallins was observed. (B) The decrease in levels of soluble proteins was determined by densitometric scanning of immunoblots. The data represent an average of three independent experiments with approximately 3-month-old mouse lenses. Three pairs of lenses were analyzed for wild type and R49Cneo/R49Cneo homozygous mice. Two pairs of lenses were analyzed for WT/R49Cneo heterozygous mice.

tions were analyzed by immunoblotting. An excess of protein extract was loaded so that protein would be detectable even in the homozygous lenses. Protein insol-
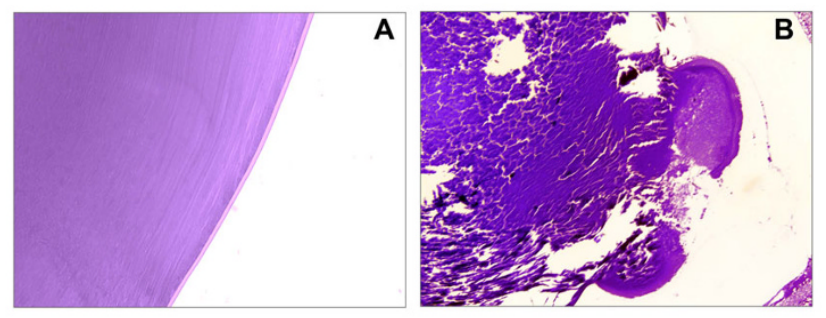

Figure 5

Posterior lens defects in R49Cneo knock-in mouse lenses. Lens sections were stained with toluidine blue and examined by bright field microscopy. (A) Lens posterior in 3month-old wild type mouse appeared normal. (B) Lens posterior of a 3-month-old R49Cneo/R49Cneo homozygous mouse showed a ruptured posterior capsule.
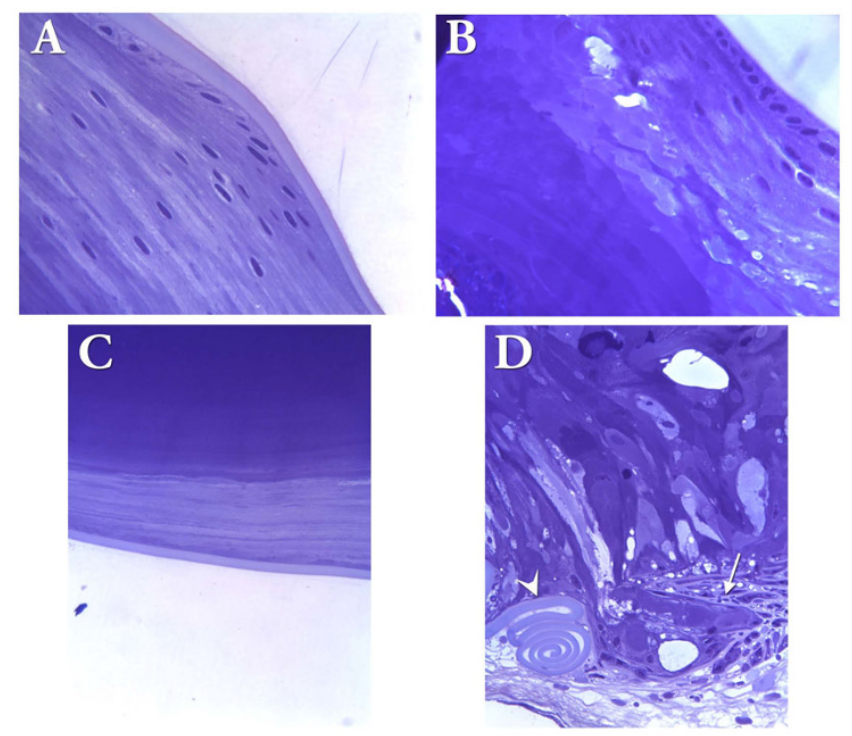

Figure 6

Posterior lens defects in R49Cneo knock-in mouse. Images are shown for lens sections from 9.5-month-old WT/ WTneo and WT/R49Cneo mouse. (A) Brightfield image of the equatorial region in a WT/WTneo mid-sagittal lens section. (B) Brightfield image of the equatorial region in a WT/R49Cneo mid-sagittal lens section. (C) Posterior region of a WT/WTneo lens shows a normal posterior capsule. (D) A WT/ R49Cneolens with posterior cataract. Note the extensive posterior rupture, migration of cells and cell debris (arrow), and compaction of the ruptured posterior capsule (arrowhead).

ubility was proportional to nuclear cataract formation by slit lamp analysis.

Examples of the posterior lens changes observed in

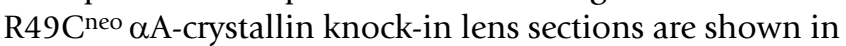
Figures 5 and 6. Posterior cataract was evident in 3month-old R49C neo/R49Cneo homozygous mice. At 9 months, WT/R49Cneo heterozygous mouse lenses showed severe posterior rupture, curling up of the posterior capsule, and migration of cells to the posterior lens (Figure 6).

At 3 weeks, histological examination of lenses revealed the presence of both small and large swollen cells or vacuoles in the lens cortical fibers of WT/R49Cneo mice, which were even more evident in R49Cneo homozygous mouse lenses (Figure 7). Early fiber formation appeared to occur normally. Swollen fiber cells begin to appear at 3 weeks postnatal in WT/R49Cneo heterozygous mice. Swollen fiber cells were confined to a distinct band of cortical fibers $\sim 100 \mu \mathrm{m}$ from the lens surface in both young and old mice. Fiber cells on either side of the swollen fibers appear to be unaffected. These swollen cells appeared to 


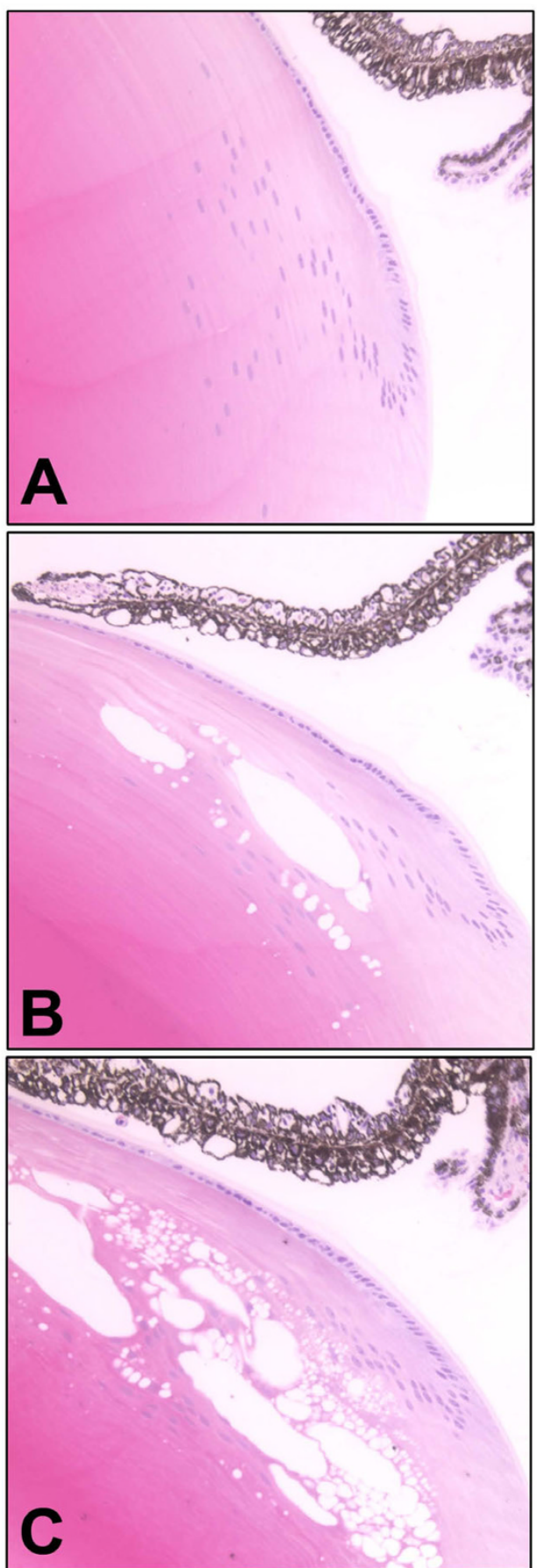

Figure 7

Morphological alterations in cortical fiber cell membranes of R49Cneo lenses. Lens sections were stained with haematoxylin/eosin. (A) Normal appearance of fiber cells in the lens equatorial region in 3-week-old wild type lenses. (B) Swollen fiber cells and separations between fiber cells in 3week-old WT/R49Cneo heterozygous lenses. (C) Gaps between fiber cells in 3-week-old R49Cneo/R49Cneo homozygous lenses. be formed by membrane rupture and fusion of cytoplasmic contents from multiple cells. Extensive undulations and interdigitations of these membranes as well as large separations between fiber cells occurred in homozygous mouse lenses. These gaps are evident in fiber cells that have detached from the capsule (Figure 6C). The proportion of swollen cells and posterior changes in WT/R49Cneo and $\mathrm{R}_{4} \mathrm{C}^{\text {neo }} / \mathrm{R} 49 \mathrm{C}^{\text {neo }}$ mice examined by histology is shown in Table 1B.

The number of swollen fiber cells increased in lenses of older homozygous mice, and extended towards the center of the lens (Figure 8). At 10 months old, a large area of aberrant fiber cells was observed. Fiber cells near the lens surface appeared normal. Newly synthesized cortical fibers appeared to form normally, but vacuoles were apparent in a band of fibers in the deep cortex $100 \mu \mathrm{m}$ from lens surface, and increased dramatically towards the lens center.

Immunofluorescence analysis with an antibody to membrane intrinsic protein (MIP) revealed that the swollen cells are enclosed by fiber cell membranes (Figure 9). Swollen cells were not found in wild type littermates or in WTneo mice. Opacification was related to defects in membrane structure of cortical lens fiber cells. Lenses were further examined by cryoimmuno electron microscopy with an antibody to $\alpha$ A-crystallin. Wild type lenses showed smooth and linear plasma membranes between the fiber cells, and $\alpha \mathrm{A}$-crystallin was restricted to the cytoplasm (Figure 10A). In contrast, fiber cell membranes of heterozygous WT/R49Cneo lenses were non-linear with extensive undulations, and significant gaps between the cells. A greater proportion of the $\alpha \mathrm{A}$-crystallin immunoreactivity was associated with fiber cell membranes in the heterozygous lenses (Figure 10B) than in wild type lenses.

\section{Discussion}

In human patients with a missense mutation in exon 1 of the gene encoding $\alpha \mathrm{A}$-crystallin (CRYAA), autosomal dominant nuclear cataract was shown to segregate in a four generation Caucasian family [1]. The $\mathrm{C}$ to $\mathrm{T}$ transition in the first base of codon 49 of CRYAA results in the non-conservative substitution of arginine 49 to cysteine (R49C) in $\alpha$ A-crystallin protein [1]. Patients with cataracts are heterozygous for this mutation, which suggests that both wild type and R49C mutant $\alpha \mathrm{A}$-crystallin subunits are expressed in these lenses in addition to wild type $\alpha \mathrm{B}$ crystallin. Unfortunately, photographic documentation of the cataracts is not available, preventing a detailed phenotypic analysis. It was shown previously that the $\alpha \mathrm{A}$-crystallin R49C mutation causes lens opacities in a knock-in mouse model, due to protein insolubilization and cell death $[42,55]$. Here a R49Cneo construct was used that 

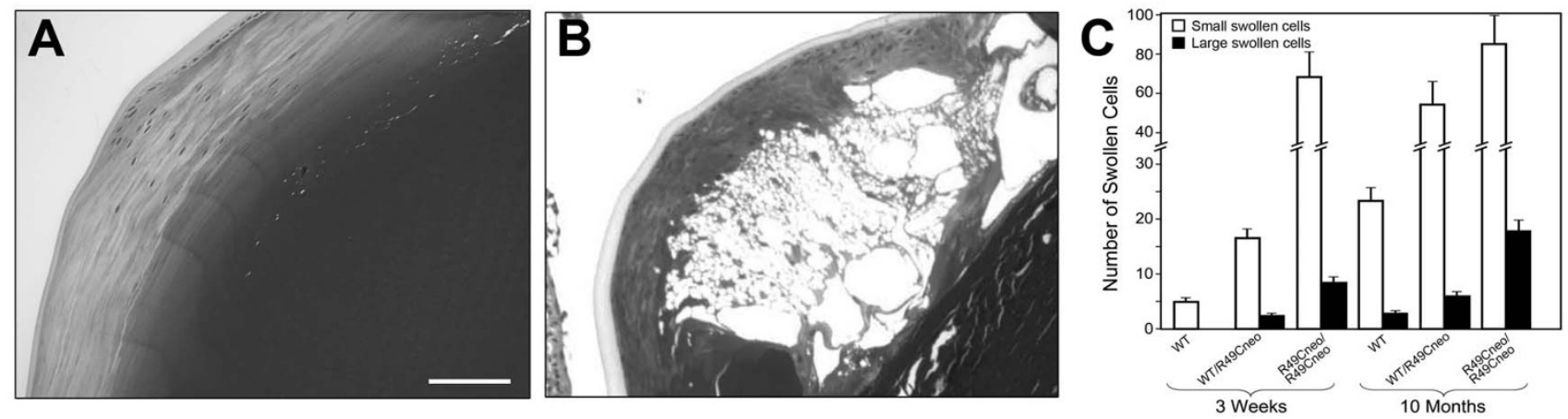

Figure 8

Morphological alterations in lenses from older wild type and R49Cneo/R49 Cneo knock-in mice. (A) Lens from wild type 10-month-old mouse with normal fiber cells near the lens surface and normal appearing fibers. (B) Large swollen cells and gaps between fiber cells in lens from I0-month-old R49Cneo/R49Cneo mouse. (C) The swollen fiber cells increased in both size and number with increased age, and extended towards the center of the lens. The number of swollen cells per lens section is shown.

causes a milder lens phenotype to show that R49C $\alpha \mathrm{A}-$ crystallin disrupts normal fiber cell organization and structure.

Homozygous mice with deletion of the floxed neor gene (R49C/R49C) have a more drastic phenotype, with smaller eyes and smaller lenses than wild type and heterozygous (WT/R49C) mutant mice [55]. This implies that the neo ${ }^{r}$ gene is suppressing expression of the R49C- $\alpha \mathrm{A}$ mutant protein, and is supported by FPLC analysis of soluble lens proteins. Indeed, previous studies indicate that selectable markers inserted in non-coding regions can affect gene expression at both the DNA and RNA level, resulting in reduced protein expression [58-60].
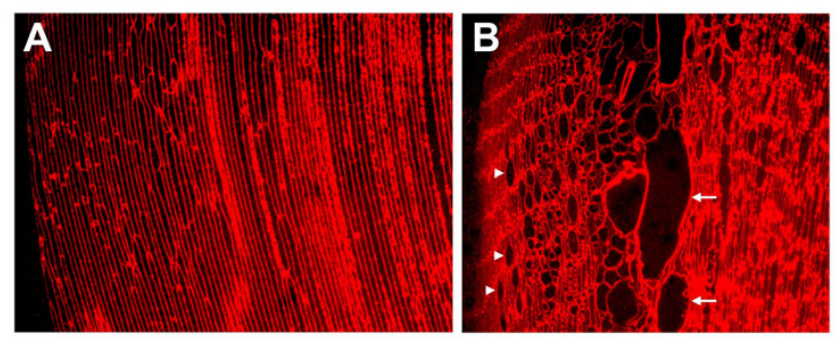

\section{Figure 9}

Immunofluorescence analysis of fiber cells in wild type and R49Cneo/R49Cneo knock-in lenses. Immunofluorescence staining of lens sections with an antibody to membrane intrinsic protein MIP and an Alexa ${ }^{568}$-conjugated secondary antibody (red) revealed a normal fiber cell morphology in wild type lenses (A), whereas the R49Cneo/ R49Cneo lenses (B) showed disorganized fiber cells and swollen cells (arrows) enclosed by membranes. Nuclei are shown by arrowheads.
The lenses of WT/R49Cneo and R49Cneo/R49Cneo mice displayed remarkable posterior lens defects and accumulation of swollen cells in the lens cortex, and developed nuclear cataracts. Both posterior lens cell defects and number of swollen fiber cells increased with age and with $\mathrm{R} 49 \mathrm{C}^{\text {neo }}$ dosage, with more defects in $\mathrm{R} 49 \mathrm{C}^{\text {neo/R49C }}$ neo mice than in WT/R49Cneo mice. The appearance of swollen fiber cells in the lens cortex may be an early marker of structural perturbation in the R49 $\mathrm{C}^{\text {neo }}$ lenses. The swollen fiber cells in deep cortical fibers of $\mathrm{R} 49 \mathrm{C}^{\text {neo }}$ lenses were evident as early as 3 weeks postnatal and increased with age, such that more than half of the lens was covered with swollen fiber cells at 10 months.

Histological and immunofluorescence analysis of the R49Cneo knock-in lenses suggests that the lens opacities observed in $\mathrm{R} 49 \mathrm{C}^{\text {neo }}$ mice are associated with membrane defects in the deep cortical fiber cells approximately 100 $\mu \mathrm{m}$ from the lens surface that result in gaps between adjacent fiber cells. Visible swelling or vacuolar areas are often limited to one or more segments of a fiber cell; hence it is likely that there are many more aberrant fiber cells than those observed in a single mid-sagittal section. Vacuolated cells indicate destruction of the fiber cells. Further studies are necessary to determine whether these vacuolar or swollen cells are formed by membrane rupture and fusion of cytoplasmic contents from multiple cells. This type of fiber cell swelling has been reported in diabetic and other models of cataract $[61,62]$. Membrane defects have also been shown to be associated with lens opacities induced by dexamethasone and mechanical stress in cultured lenses, both of which are associated with the loss of cadherin junctions $[17,63]$. The interaction between $\alpha \mathrm{A}$-crystallin and fiber cell membranes is well-established $[16,64,65]$, and has been shown to increase with lens 

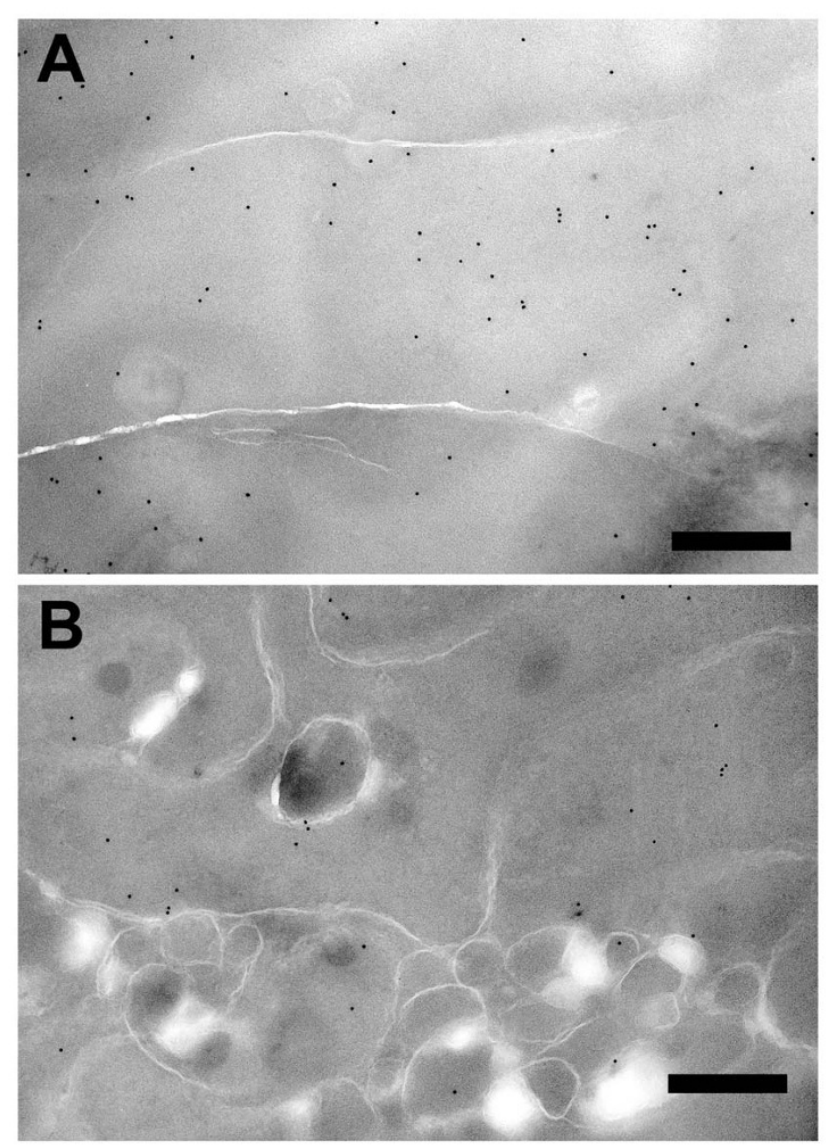

Figure 10

Cryoimmuno electron microscopic analysis of wild type and R49Cneo/R49 Cneo knock-in lenses. Lenses expressing either wild type or heterozygous $\mathrm{R} 49 \mathrm{Cneo/}$ $R 49 C^{\text {neo }} \alpha A$-crystallin were labeled with an antibody to $\alpha A$ crystallin and analyzed by cryoimmuno electron microscopy. (A) Wild type lenses showed linear fiber cell membranes. Immunogold labeling (black dots) showed that $\alpha \mathrm{A}$-crystallin was restricted to the cytoplasm. (B) Heterozygous WT/ R49C neo $\alpha A$-crystallin lenses had several gold particles on the fiber cell membranes. Furthermore, the linearity of lens fiber cell membranes was lost, and significant gaps between cells were apparent.

aging and in cataracts [66]. In the current study, membrane alterations in WT/R49Cneo mouse lenses were confirmed by ultrastructural analysis. Cryoimmuno electron microscopic analysis of heterozygous $\mathrm{R} 49 \mathrm{C}^{\text {neo }}$ lenses with an antibody specific to $\alpha$ A-crystallin showed loss of membrane linearity in the cortical fiber cells, undulations of the membranes, and significant gaps between cells. Furthermore, more $\alpha \mathrm{A}$-crystallin was membrane-associated in the heterozygous knock-in lens fiber cells than in the wild type controls. Our studies also showed that the solubility of $\alpha \mathrm{A}$-crystallin is decreased in the $\mathrm{R} 49 \mathrm{C}^{\text {neo }}$ lenses, which may have a profound effect on its binding to lens fiber cell membranes [67].
Evidence in the literature suggests that loss of $\alpha$-crystallin function through gene knockout or mutation alters protein homeostasis by increasing the abundance of aggregation-prone proteins. This may result in altered proteinprotein interactions, and protein insolubility $[55,68]$. Correct protein conformation is essential for normal cell function, and proteotoxic stress due to protein aggregation and loss of protein homeostasis is known to be associated with aging and disease [69].

In the present work, no significant defects were found in $\mathrm{WT} / \mathrm{W} T^{\text {neo }}$ and $\mathrm{W} T^{\text {neo }} / \mathrm{WT}^{\text {neo }}$ lenses. In targeted gene deletion studies in mice, $\alpha \mathrm{A}+/$ - heterozygous mouse lenses do not show lens opacification, whereas $\alpha \mathrm{A}-/-$ homozygous lenses develop cataracts at an early age [24]. Most of the defects in $\alpha \mathrm{A}$-crystallin knockout ( $\alpha \mathrm{A}-/-)$ mouse lenses are due to protein insolubility in the lens nucleus and cell death in the lens epithelium [24,31]; no defects in fiber cell elongation or fiber cell morphology were reported. Our previous study showed that lens defects in R49C/ R49C knock-in mice are the result of a drastic alteration of lens fiber cell morphology, although early fiber cell elongation is normal [55]. In the present study, we did not observe as strong an effect on lens fiber morphology in young R49Cneo mice as in R49C/R49C mice, but did observe varied posterior lens defects beginning at an early postnatal age, as well as posterior migration of nuclei at older ages and posterior rupture. Such posterior migration of epithelial cells has been reported in human posterior subcapsular cataracts $[70,71]$. A disorganization of the postequatorial fiber zone was also observed, which has been reported in human posterior subcapsular cataracts. Thus, the R49Cneo mouse model system appears to be an effective model for human posterior subcapsular cataracts.

\section{Conclusion}

In summary, the results of the present work, combined with previously published data, provide evidence that $\alpha \mathrm{A}$ crystallin plays a role in the structure of fiber cell membranes, and is involved in the formation of hereditary cataracts. The present study provides insight into the in vivo effects of the R49C mutation of $\alpha \mathrm{A}$-crystallin on the lens, and extends the findings of previous studies $[1,42]$. In mice, expression of the R49C $\alpha \mathrm{A}$-crystallin mutant protein in the presence of the neo ${ }^{r}$ gene causes posterior cataracts with posterior migration of epithelial cell nuclei, and demonstrates that the mutant protein affects the integrity of lens fiber cells in the deep cortex. These changes are milder than those observed when the neo ${ }^{\mathrm{r}}$ gene is deleted. By studying homozygous $\mathrm{R} 49 \mathrm{C}^{\text {neo/R49Cneo mice that }}$ begin to lose transparency around 2 months of age, compared with the typical onset at birth in R49C/R49C mice, the author has obtained additional information about the progression of cataracts. The R49Cneo mice described in the present study are one of only a few models available 
to study hereditary posterior cataract, a common human lens pathology.

\section{Competing interests}

The author declares no competing interests.

\section{Authors' contributions}

The author performed slit lamp biomicroscopy, microscopic analysis of lens sections, and drafted the manuscript and subsequent revisions

\section{Acknowledgements}

The author thanks Michael Casey and Sue Penrose in the Molecular Biology Core laboratory of the Department of Ophthalmology and Visual Sciences for their help in generating the knock-in mice, Wandy Beatty for performing cryo-immuno electron microscopic analysis, and Belinda McMahan and other laboratory staff for technical help. The author is grateful to Mark Petrash and Terry Griest for help with the FPLC analysis. This work is supported by National Eye Institute (NIH) grant R0IEY0568I to UPA, and awards to the Department of Ophthalmology and Visual Sciences at Washington University from a Research to Prevent Blindness, Inc. Unrestricted grant, and the NIH Vision Core Grant P30 EY 02687.

\section{References}

I. Mackay DS, Andley UP, Shiels A: Cell death triggered by a novel mutation in the alphaA-crystallin gene underlies autosomal dominant cataract linked to chromosome 2 lq. Eur J Hum Genet 2003, I I ( I 0):784-793.

2. Graw J: Congenital hereditary cataracts. Int J Dev Biol 2004, 48(8-9): $1031-1044$.

3. Graw J: Genetics of crystallins: cataract and beyond. Exp Eye Res 2009, 88(2): 173-189.

4. Hejtmancik JF, Smaoui N: Molecular genetics of cataract. Dev Ophthalmol 2003, 37:67-82.

5. Shiels A, Hejtmancik JF: Genetic origins of cataract. Arch Ophthalmol 2007, I25(2): 165-173.

6. Bloemendal H, de Jong W, Jaenicke R, Lubsen NH, Slingsby C, Tardieu $A$ : Ageing and vision: structure, stability and function of lens crystallins. Prog Biophys Mol Biol 2004, 86(3):407-485.

7. Ingolia TD, Craig EA: Four small Drosophila heat shock proteins are related to each other and to mammalian alphacrystallin. Proc Natl Acad Sci USA 1982, 79(7):2360-2364.

8. Horwitz J: Alpha-crystallin can function as a molecular chaperone. Proc Natl Acad Sci USA 1992, 89(21): 10449-10453.

9. Horwitz J: Alpha crystallin: The quest for a homogeneous quaternary structure. Exp Eye Res 2009, 88: 190-194.

10. Aquilina JA, Benesch JL, Bateman OA, Slingsby C, Robinson CV: Polydispersity of a mammalian chaperone: mass spectrometry reveals the population of oligomers in alphaB-crystallin. Proc Natl Acad Sci USA 2003, 100(19):1061 I-10616.

II. Ghosh JG, Shenoy AK Jr, Clark Jl: $\mathbf{N}$ - and C-Terminal motifs in human alphaB crystallin play an important role in the recognition, selection, and solubilization of substrates. Biochemistry 2006, 45(46): I 3847- I 3854.

12. Sun TX, Akhtar NJ, Liang J]: Subunit exchange of lens alpha-crystallin: a fluorescence energy transfer study with the fluorescent labeled alphaA-crystallin mutant $\mathrm{W} 9 \mathrm{~F}$ as a probe. FEBS Lett I998, 430(3):40I-404.

13. Sun TX, Liang JJ: Intermolecular exchange and stabilization of recombinant human alphaA- and alphaB-crystallin. J Biol Chem 1998, 273(I):286-290.

14. Van Montfort R, Slingsby C, Vierling E: Structure and function of the small heat shock protein/alpha-crystallin family of molecular chaperones. Adv Protein Chem 200I, 59:105-156.

15. Cobb BA, Petrash JM: alpha-Crystallin chaperone-like activity and membrane binding in age-related cataracts. Biochemistry 2002, 4 I (2):483-490.

16. Ifeanyi $F$, Takemoto $L$ : Alpha crystallin from human cataractous vs. normal lenses: change in binding to lens membrane. Exp Eye Res 1990, 50(1): 113-116.
17. Zhou J, Leonard M, Van Bockstaele E, Menko AS: Mechanism of Src kinase induction of cortical cataract following exposure to stress: destabilization of cell-cell junctions. Mol Vis 2007, I3:|298-1310.

18. MacRae TH: Structure and function of small heat shock/alphacrystallin proteins: established concepts and emerging ideas. Cell Mol Life Sci 2000, 57(6):899-913.

19. Maddala R, Rao VP: alpha-Crystallin localizes to the leading edges of migrating lens epithelial cells. Exp Cell Res 2005, 306(I):203-215.

20. Perng MD, Wen SF, van den IP, Prescott AR, Quinlan RA: Desmin aggregate formation by $R I 20 \mathrm{G}$ alphaB-crystallin is caused by altered filament interactions and is dependent upon network status in cells. Mol Biol Cell 2004, I 5(5):2335-2346.

2I. Quinlan R: Cytoskeletal competence requires protein chaperones. Prog Mol Subcell Biol 2002, 28:219-233.

22. $\mathrm{Xi} \mathrm{JH}$, Bai F, McGaha R, Andley UP: Alpha-crystallin expression affects microtubule assembly and prevents their aggregation. Faseb J 2006, 20(7):846-857.

23. Robinson ML, Overbeek PA: Differential expression of alpha Aand alpha B-crystallin during murine ocular development. Invest Ophthalmol Vis Sci 1996, 37(I I):2276-2284.

24. Brady JP, Garland D, Duglas-Tabor Y, Robison WG Jr, Groome A, Wawrousek EF: Targeted disruption of the mouse alpha Acrystallin gene induces cataract and cytoplasmic inclusion bodies containing the small heat shock protein alpha B-crystallin. Proc Natl Acad Sci USA 1997, 94(3):884-889.

25. Brady JP, Garland DL, Green DE, Tamm ER, Giblin FJ, Wawrousek EF: AlphaB-crystallin in lens development and muscle integrity: a gene knockout approach. Invest Ophthalmol Vis Sci 200I, 42(I 2):2924-2934.

26. Andley UP: Crystallins in the eye: Function and pathology. Prog Retin Eye Res 2007, 26(I):78-98.

27. Andley UP, Song Z, Wawrousek EF, Bassnett S: The molecular chaperone alphaA-crystallin enhances lens epithelial cell growth and resistance to UVA stress. J Biol Chem 1998, 273(47):3|252-3|26|.

28. Srinivasan AN, Nagineni CN, Bhat SP: alpha A-crystallin is expressed in non-ocular tissues. I Biol Chem 1992, 267(32):23337-2334I.

29. Andley UP, Song Z, Wawrousek EF, Fleming TP, Bassnett S: Differential protective activity of alpha A- and alphaB-crystallin in lens epithelial cells. J Biol Chem 2000, 275(47):36823-3683I.

30. Morozov V, Wawrousek EF: Caspase-dependent secondary lens fiber cell disintegration in alphaA-/alphaB-crystallin doubleknockout mice. Development 2006, I33(5):8|3-82I.

31. Xi JH, Bai F, Andley UP: Reduced survival of lens epithelial cells in the alphaA-crystallin-knockout mouse. J Cell Sci 2003, I 16(Pt 6):1073-1085.

32. Litt M, Kramer P, LaMorticella DM, Murphey W, Lovrien EW, Weleber RG: Autosomal dominant congenital cataract associated with a missense mutation in the human alpha crystallin gene CRYAA. Hum Mol Genet 1998, 7(3):47I-474.

33. Liu Y, Zhang X, Luo L, Wu M, Zeng R, Cheng G, Hu B, Liu B, Liang JJ, Shang F: A Novel \{alpha\}B-Crystallin Mutation Associated with Autosomal Dominant Congenital Lamellar Cataract. Invest Ophthalmol Vis Sci 2006, 47(3): 1069-1075.

34. Pras E, Frydman M, Levy-Nissenbaum E, Bakhan T, Raz J, Assia EI, Goldman B, Pras E: A nonsense mutation (W9X) in CRYAA causes autosomal recessive cataract in an inbred Jewish Persian family. Invest Ophthalmol Vis Sci 2000, 4I (I I):35 I I-35 I 5.

35. Vanita V, Singh JR, Hejtmancik JF, Nuernberg P, Hennies HC, Singh D, Sperling K: A novel fan-shaped cataract-microcornea syndrome caused by a mutation of CRYAA in an Indian family. Mol Vis 2006, I2:518-522.

36. Vicart P, Caron A, Guicheney P, Li Z, Prevost MC, Faure A, Chateau $D$, Chapon F, Tome F, Dupret JM, et al.: A missense mutation in the alphaB-crystallin chaperone gene causes a desminrelated myopathy. Nat Genet 1998, 20(1):92-95.

37. Richter L, Flodman P, Barria von-Bischhoffshausen F, Burch D, Brown S, Nguyen L, Turner J, Spence MA, Bateman JB: Clinical variability of autosomal dominant cataract, microcornea and corneal opacity and novel mutation in the alpha $A$ crystallin gene (CRYAA). Am J Med Genet A 2008, I 46(7):833-842.

38. Andley UP: Crystallins and hereditary cataracts: molecular mechanisms and potential for therapy. Expert Rev Mol Med 2006, 8(25): $1-19$. 
39. Santhiya ST, Soker T, Klopp N, Illig T, Prakash MV, Selvaraj B, Gopinath PM, Graw J: Identification of a novel, putative cataractcausing allele in CRYAA (G98R) in an Indian family. Mol Vis 2006, 12:768-773

40. Koteiche HA, McHaourab HS: Mechanism of a hereditary cataract phenotype. Mutations in alphaA-crystallin activate substrate binding. I Biol Chem 2006, 28 I (20): I 4273- I 4279.

41. Treweek TM, Rekas A, Lindner RA, Walker MJ, Aquilina JA, Robinson CV, Horwitz J, Perng MD, Quinlan RA, Carver JA: RI 20G alphaBcrystallin promotes the unfolding of reduced alpha-lactalbumin and is inherently unstable. Febs J 2005, 272(3):7II-724.

42. Andley UP, Hamilton PD, Ravi N: Mechanism of insolubilization by a single-point mutation in alphaA-crystallin linked with hereditary human cataracts. Biochemistry 2008 47(36):9697-9706.

43. Bova MP, Yaron O, Huang Q, Ding L, Haley DA, Stewart PL, Horwitz $\mathrm{J}$ : Mutation RI20G in alphaB-crystallin, which is linked to a desmin-related myopathy, results in an irregular structure and defective chaperone-like function. Proc Natl Acad Sci USA 1999, 96(I I):6|37-6|42.

44. Murugesan R, Santhoshkumar P, Sharma KK: Cataract-causing alphaAG98R mutant shows substrate-dependent chaperone activity. Mol Vis 2007, 13:2301-2309.

45. Shroff NP, Cherian-Shaw M, Bera S, Abraham EC: Mutation of R I I 6C results in highly oligomerized alpha A-crystallin with modified structure and defective chaperone-like function. Biochemistry 2000, 39(6): | 1420-1426.

46. Singh D, Raman B, Ramakrishna T, Rao Ch M: Mixed oligomer formation between human alphaA-crystallin and its cataractcausing G98R mutant: structural, stability and functional differences. I Mol Biol 2007, 373(5): I 293-1304.

47. de Jong WW, Caspers GJ, Leunissen JA: Genealogy of the alphacrystallin - small heat-shock protein superfamily. Int J Biol Macromol 1998, 22(3-4): $15 \mid-162$.

48. Biswas A, Miller A, Oya-lto T, Santhoshkumar P, Bhat M, Nagaraj RH: Effect of site-directed mutagenesis of methylglyoxal-modifiable arginine residues on the structure and chaperone function of human alphaA-crystallin. Biochemistry 2006, 45(I4):4569-4577.

49. Hsu CD, Kymes S, Petrash JM: A transgenic mouse model for human autosomal dominant cataract. Invest Ophthalmol Vis Sci 2006, 47(5):2036-2044

50. Andley UP, Patel HC, Xi JH: The RII6C mutation in alpha Acrystallin diminishes its protective ability against stressinduced lens epithelial cell apoptosis. J Biol Chem 2002, 277(1 2): $10178-10186$.

5I. Graw J, Loster J, Soewarto D, Fuchs H, Meyer B, Reis A, Wolf E, Balling R, Hrabe de Angelis M: Characterization of a new, dominant VI24E mutation in the mouse alphaA-crystallin-encoding gene. Invest Ophthalmol Vis Sci 200I, 42(I 2):2909-29I5.

52. Graw J: Cataract mutations and lens development. Prog Retin Eye Res 1999, 18(2):235-267.

53. Graw J: The genetic and molecular basis of genetic eye defects. Nature Reviews Genetics 2003, 4(I I):876-888.

54. Xia CH, Liu H, Chang B, Cheng C, Cheung D, Wang M, Huang Q, Horwitz J, Gong $X$ : Arginine 54 and Tyrosine 118 residues of \{alpha\}A-crystallin are crucial for lens formation and transparency. Invest Ophthalmol Vis Sci 2006, 47(7):3004-30I0.

55. Xi JH, Bai F, Gross J, Townsend RR, Menko AS, Andley UP: Mechanism of small heat shock protein function in vivo: a knock-in mouse model demonstrates that the R49C mutation in alpha A-crystallin enhances protein insolubility and cell death. J Biol Chem 2008, 283(9):580I-58I4.

56. Andley UP, Mathur S, Griest TA, Petrash JM: Cloning, expression, and chaperone-like activity of human alphaA-crystallin. J Biol Chem 1996, 27I(50):31973-31980.

57. Bai $F, X i J H$, Andley UP: Up-regulation of tau, a brain microtubule-associated protein, in lens cortical fractions of aged alphaA-, alphaB-, and alphaA/B-crystallin knockout mice. Mol Vis 2007, 13:1589-1600

58. Meyers EN, Lewandoski M, Martin GR: An Fgf8 mutant allelic series generated by Cre- and Flp-mediated recombination. Nat Genet 1998, I8(2): |36-141.

59. Scacheri PC, Crabtree JS, Novotny EA, Garrett-Beal L, Chen A Edgemon KA, Marx SJ, Spiegel AM, Chandrasekharappa SC, Collins FS: Bidirectional transcriptional activity of PGK-neomycin and unexpected embryonic lethality in heterozygote chimeric knockout mice. Genesis 200I, 30(4):259-263.

60. Shannon MB, Patton BL, Harvey SJ, Miner JH: A hypomorphic mutation in the mouse laminin alpha5 gene causes polycystic kidney disease. J Am Soc Nephrol 2006, I 7(7): I9|3-1922.

6I. Bond J, Green C, Donaldson P, Kistler J: Liquefaction of cortical tissue in diabetic and galactosemic rat lenses defined by confocal laser scanning microscopy. Invest Ophthalmol Vis Sci 1996, 37(8): $1557-1565$

62. Tunstall MJ, Eckert R, Donaldson P, Kistler J: Localised fibre cell swelling characteristic of diabetic cataract can be induced in normal rat lens using the chloride channel blocker 5-nitro-2(3-phenylpropylamino) benzoic acid. Ophthalmic Res 1999, 3I(4):3I 7-320.

63. Lyu J, Kim JA, Chung SK, Kim KS, Joo CK: Alteration of cadherin in dexamethasone-induced cataract organ-cultured rat lens. Invest Ophthalmol Vis Sci 2003, 44(5):2034-2040.

64. Ifeanyi F, Takemoto L: Specificity of alpha crystallin binding to the lens membrane. Curr Eye Res 1990, 9(3):259-265.

65. Ifeanyi F, Takemoto L: Involvement of the $\mathbf{N}$-terminal region in alpha-crystallin-lens membrane recognition. Exp Eye Res I991, 53(3):305-308.

66. Boyle DL, Takemoto L: EM immunolocalization of alpha-crystallins: association with the plasma membrane from normal and cataractous human lenses. Curr Eye Res 1996, I 5(5):577-582.

67. Cobb BA, Petrash JM: Structural and functional changes in the alpha A-crystallin RI I 6C mutant in hereditary cataracts. Biochemistry 2000, 39(5 I): I579|-I5798.

68. McHaourab HS, Dodson EK, Koteiche HA: Mechanism of chaperone function in small heat shock proteins. Two-mode binding of the excited states of T4 lysozyme mutants by alphaAcrystallin. J Biol Chem 2002, 277(43):40557-40566.

69. Morimoto RI: Proteotoxic stress and inducible chaperone networks in neurodegenerative disease and aging. Genes Dev 2008, 22(I I): 1427-I438.

70. Eshaghian J, Streeten BW: Human posterior subcapsular cataract. An ultrastructural study of the posteriorly migrating cells. Arch Ophthalmol 1980, 98(I): I34-143.

7I. Streeten BW, Eshaghian J: Human posterior subcapsular cataract. A gross and flat preparation study. Arch Ophthalmol 1978, 96(9): 1653-1658

\section{Pre-publication history}

The pre-publication history for this paper can be accessed here:

http://www.biomedcentral.com/1471-2415/9/4/prepub

Publish with BioMed Central and every scientist can read your work free of charge

"BioMed Central will be the most significant development for disseminating the results of biomedical research in our lifetime. "

Sir Paul Nurse, Cancer Research UK

Your research papers will be:

- available free of charge to the entire biomedical community

- peer reviewed and published immediately upon acceptance

- cited in PubMed and archived on PubMed Central

- yours - you keep the copyright 